\title{
Cancer-Associated Thrombosis: A Clinical Scoping Review of the Risk Assessment Models Across Solid Tumours and Haematological Malignancies
}

\author{
Manar Mosaad' \\ Mohamed Hassan Elnaem (iD ${ }^{2}$ \\ Ejaz Cheema (iD) ${ }^{3}$ \\ Ismail Ibrahim' \\ Jamalludin Ab Rahman (iD ${ }^{4}$ \\ Ahlam Naila Kori ${ }^{5}$ \\ How Soon Hin \\ 'Department of Internal Medicine, \\ Faculty of Medicine, International Islamic \\ University Malaysia, Kuantan, Pahang, \\ Malaysia; ${ }^{2}$ Department of Pharmacy \\ Practice, Faculty of Pharmacy, \\ International Islamic University Malaysia, \\ Kuantan, Pahang, Malaysia; ${ }^{3}$ School of \\ Pharmacy, University of Birmingham, \\ Birmingham, BI5 2TT, UK; ${ }^{4}$ Department \\ of Community Medicine, Faculty of \\ Medicine, International Islamic University \\ Malaysia, Kuantan, Pahang, Malaysia; \\ ${ }^{5}$ Haematology Unit, Tengku Ampuan \\ Afzan Hospital, Kuantan, Pahang, Malaysia
}

Correspondence: Ejaz Cheema School of Pharmacy, University of Birmingham, Edgbaston, Birmingham, BI5 2TT, UK

Email manarmosaad@gmail.com;

E.Cheema@bham.ac.uk

\begin{abstract}
Cancer-associated thrombosis (CAT) is a leading cause of death in cancer patients receiving outpatient chemotherapy. The latest guidelines emphasize stratifying the patients in terms of CAT risks periodically. Multiple risk assessment models (RAMs) were developed to classify patients and guide thromboprophylaxis to high-risk patients. This study aimed to discuss and highlight different RAMs across various malignancy types with their related advantages and disadvantages. A scoping review was conducted using predefined search terms in three scientific databases, including Google Scholar, Science Direct, and PubMed. The search for studies was restricted to original research articles that reported risk assessment models published in the last thirteen years (between 2008 and 2021) to cover the most recently published evidence following the development of the principal risk assessment score in 2008. Data charting of the relevant trials, scores, advantages, and disadvantages were done iteratively considering the malignancy type. Of the initially identified 1115 studies, 39 studies with over 67,680 patients were included in the review. In solid organ malignancy, nine risk assessment scores were generated. The first and most known Khorana risk score still offers the best available risk assessment model when used for high-risk populations with a threshold of 2 and above. However, KRS has a limitation of failure to stratify low-risk patients. The COMPASS-CAT score showed the best performance in the lung carcinoma patients who have a higher prevalence of thrombosis than other malignancy subtypes. In testicular germ cell tumours, Bezan et al RAM is a validated good discriminatory RAM for this malignancy subtype. CAT in haematological malignancy seems to be under-investigated and has multiple disease-related, and treatment-related confounding factors. AL-Ani et al score performed efficiently in acute leukemia. In multiple myeloma, both SAVED and IMPEDED VTE scores showed good performance. Despite the availability of different disease-specific scores in lymphoma-related thrombosis, the standard of care needs to be redefined.
\end{abstract}

Keywords: thrombosis, cancer, prophylaxis, risk assessment

\section{Introduction}

The link between cancer and its predisposing risk of thrombosis has been well identified. ${ }^{1}$ Compared to the general population, cancer patients have a 7-times higher risk of thromboembolism. ${ }^{2}$ Cancer-associated thrombosis (CAT) is the second most prevalent mortality cause in malignancy patients, following the mortality caused by the direct impact of cancer. ${ }^{3}$ Mortality risk increases fourfold 
with advanced malignancy. Furthermore, CAT is a significant cause of morbidity for patients, resulting in a lower quality of life and more frequent hospitalization. ${ }^{4}$ There is a $5-10 \%$ probability of developing CAT among patients on chemotherapy within the first year following the disease diagnosis. ${ }^{5}$ The yearly incidence of CAT varies widely from $1.4 \%$ to $10 \%$ and up to $20 \%$ in specific cases attributed to a wide range of presentation variations such as the cancer type, stage, patient characteristics, and treatment protocols. ${ }^{6}$ Since thromboprophylaxis may reduce CAT rates by up to $50 \%$ in high-risk patients, extensive research has been done to establish accurate and discriminative risk assessment models (RAM) that can distinguish high-risk CAT patients in whom thromboprophylaxis is most likely to confer significant benefits and overweight any possible risks. ${ }^{7}$

Given the high CAT-related morbidity and mortality, thromboprophylaxis is recommended for moderate to high VTE risk ambulatory patients undergoing chemotherapy based on the type of malignancy or by using a valid risk evaluation model. ${ }^{8,9}$ The first risk assessment score was introduced in 2008 by Alok Khorana et al through the most known and validated model for risk evaluation, The Khorana Risk Score (KRS). ${ }^{10}$ A systematic review evaluated the performance of the KRS from 2008 till 2018 and included 55 cohorts $(\mathrm{N}=34,555)$ showed consistency in identifying ambulatory patients who are at high risk of developing VTE; however, patients with low scores (0 or 1) were still experiencing a significant rate of VTE incidence. $^{11}$ In the recent AVERT and CASSINI studies measuring the performance of thromboprophylaxis use of direct oral anticoagulant (DOAC) in ambulatory cancer patients, the used KRS $\geq 2$ showed a substantial decline in the overall VTE burden. ${ }^{12,13}$

It was revealed that the KRS has numerous limitations, particularly in the low-risk group; thus, several risk assessment scores were also developed. Although the majority of the scores are pan-malignant RAM, other diseases specific RAM also developed. This raises concern about whether the availability of a more specific RAM would yield an even better risk reduction. Up to the best of the authors' knowledge, there is a lack of evidence to discuss and highlight different RAMs across various malignancy types with their related advantages and disadvantages. This review aimed to discuss and summarize available risk assessment models/scores in various malignancies and identify their relative performance and advantages.

\section{Methods}

The framework for performing scoping reviews was the main methodological base for performing this scoping review. We followed the stepwise illustrated approach as proposed by H. Arksey \& L. O’Malley and advanced further by Levac et al. ${ }^{14,15}$

\section{Identifying the Research Questions}

This review focussed on studying the risk assessment models of cancer-associated thrombosis. The following research questions guided the process of including studies, extracting and summarising assessment models, and their main characteristics, advantages, and disadvantages:

What are available risk assessment models for cancerassociated thrombosis in ambulatory cancer patients undergoing chemotherapy?

Which score has the most comparative discriminative performance among risk assessment models in each malignancy type among ambulatory cancer patients?

\section{Identifying Relevant Studies}

We included original research articles published between January 2008 and January 2021 that reported risk assessment models in cancer-associated thrombosis (Table 1). The search for studies was restricted to the last thirteen years to review the most recently published evidence following the development of the principal risk assessment score in 2008. (Table 2). A comprehensive search in three databases, Google Scholar, PubMed, and ScienceDirect, was performed to retrieve relevant studies using predefined terms.

Table I Inclusion Criteria

\begin{tabular}{|l|l|}
\hline Category & Inclusion Criteria \\
\hline $\begin{array}{l}\text { Language of } \\
\text { publication }\end{array}$ & English \\
\hline $\begin{array}{l}\text { Year of } \\
\text { publication }\end{array}$ & JAN 2008-JAN 202I \\
\hline Publication type & Original research articles \\
\hline $\begin{array}{l}\text { Outcomes } \\
\text { measures }\end{array}$ & $\begin{array}{l}\text { Risk assessment model discriminative } \\
\text { performance }\end{array}$ \\
\hline Methodology & $\begin{array}{l}\text { Studies of derivation, validation, or comparison of } \\
\text { risk assessment models were eligible for inclusion }\end{array}$ \\
\hline Patients & $\begin{array}{l}\text { Ambulatory active cancer patients. } \\
\text { Currently receiving chemotherapy or planned for } \\
\text { chemotherapy }\end{array}$ \\
\hline
\end{tabular}



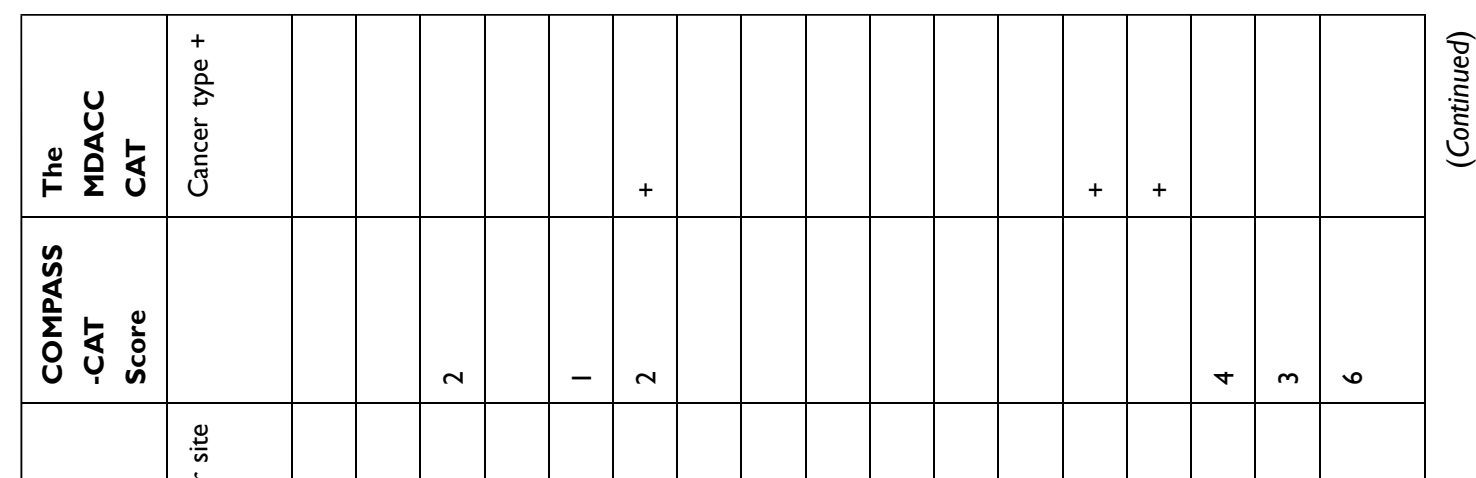

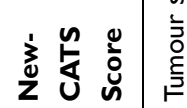
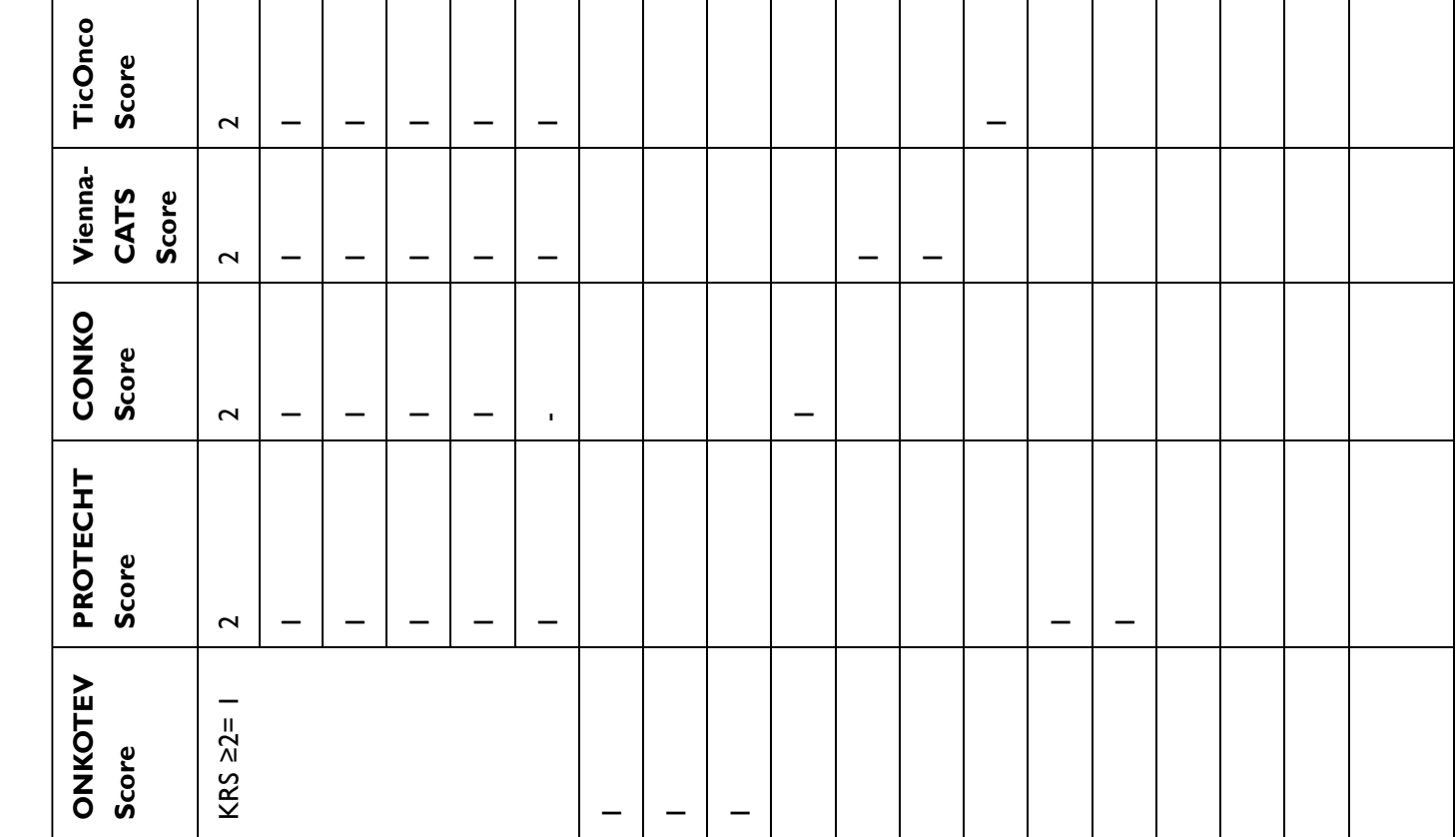

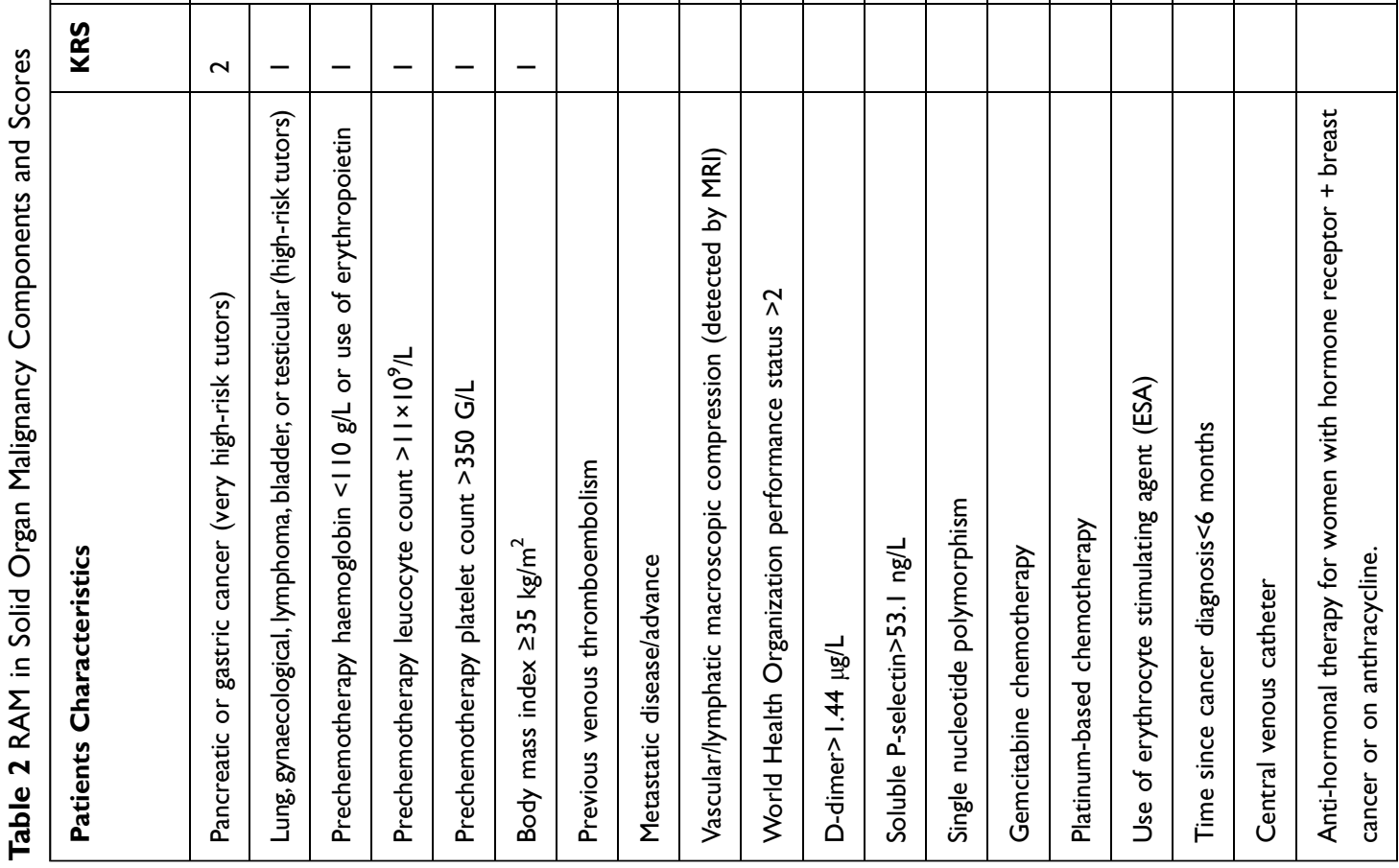




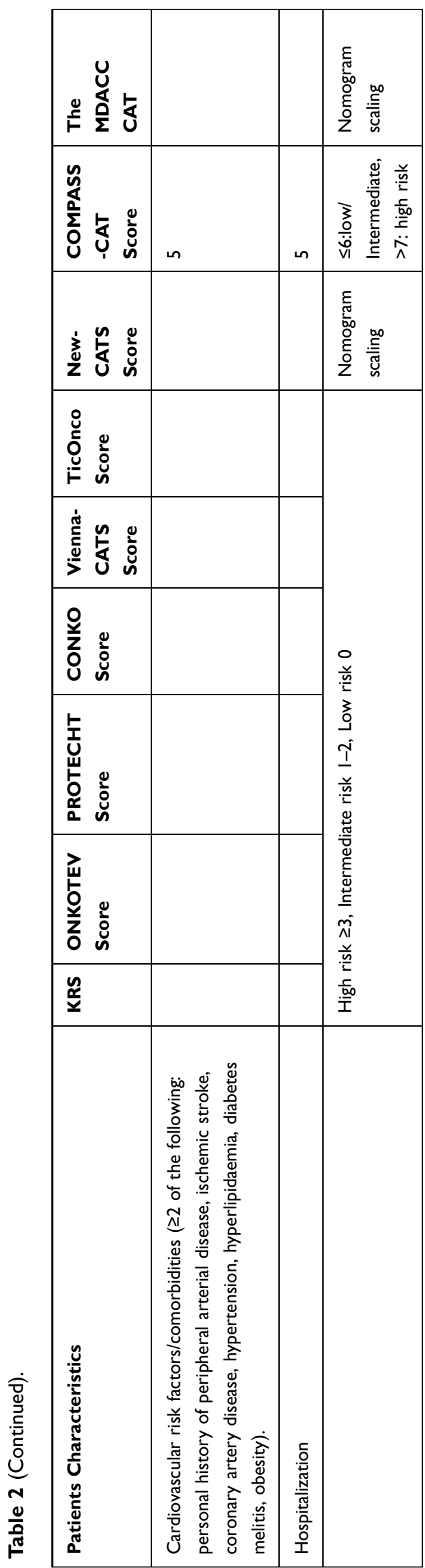

The search terms included ("cancer-associated thrombosis"), ("CAT"), ("risk assessment model"), ("risk assessment score"), ("RAM"), ("risk stratification"), ("prediction tool"), and ("predictive score"). Figure 1 shows the flow chart of the process of inclusion of the studies.

\section{Study Selection}

Two independent reviewers performed the initial identification of studies for potential inclusion at this stage according to the predefined inclusion criteria presented in Table 1. As suggested by the followed methodological approach, meetings were conducted regularly to select the studies. Further involvement of an independent reviewer was considered to resolve any conflicts or discrepancies in the included studies. Finally, full-text articles published in the last thirteen years that met the inclusion criteria were considered for inclusion (Table 1).

\section{Charting the Data}

An iterative pattern of charting the data was adopted using a form specifically to extract relevant information consistent with the above-mentioned research questions. The included variables were study author, year, main score components, advantages, disadvantages, conducted validation trials, and the key findings. Independent data extraction for the first five studies was performed and evaluated. A consistent data extraction pattern was then completed for the remaining included studies concerning the designed extraction form.

\section{Compiling, Summarizing, and Reporting the Findings}

A descriptive analysis of the retrieved data was conducted. Reporting the key findings was done in a reliable pattern to the proposed research questions and the main work objectives. Based on the malignancy subtypes, a summary of the advantages and disadvantages of the risk assessment models was discussed and tabulated. For cancer-associated thrombosis, the performance of the risk assessment models compared to others was highlighted.

\section{Results and Discussion}

Of the initially identified 1115 studies, 39 studies with over 67,680 patients were included in the review. Overall, the review identified three major malignancy subtypes with well-defined dedicated risk assessment models: solid organ, lung, and haematological malignancies. Few RAMs that have been validated for use across all 


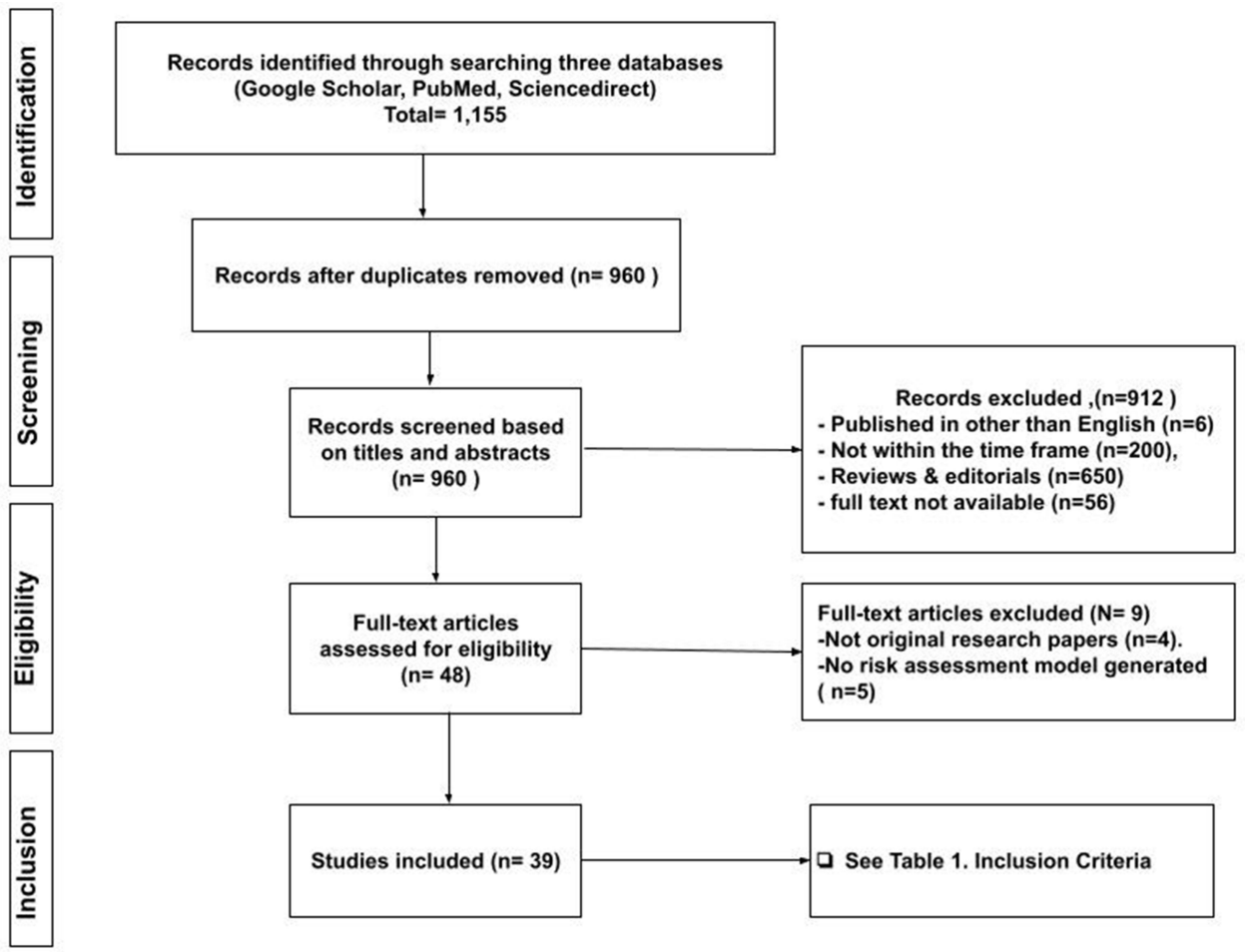

Figure I Flowchart for selecting the studies included in the scoping review.

malignancy types were discussed. Three main sections as per malignancy types are discussed in the following part.

\section{Risk Assessment Model (RAM) in Solid Organ Tumour}

The initial risk assessment model, KRS (2008), was pancancerous for all types of malignancies and not diseasespecific. However, the validation studies showed suboptimal KRS performance in certain malignancies such as lung carcinoma and haematological malignancies that will be individually discussed later. The RAMs currently available for thrombosis risk stratification in solid organ malignancy are KRS being the first and most known score, Khorana modification scores (CATS Score, PROTECHT Score, CONKO Score, TiC-Onco risk score, and ONKOTEV Score), and the new generation models (The COMPASS-CAT score, new Vienna-CATS score, and The MDACC CAT model). These scores have similarities and unique features for each of them, as shown in Table 2.

The majority of these RAMs have been derived through retrospective statistical analysis of ambulatory cancer patient cohorts subsequently validated. We reviewed all these trials with over 41,896 patients in derivation and validation studies. These RAMs vary widely; hence while some are feasible, some have limitations and disadvantages if considering the real-life setting, as discussed below. A list of the studies involved different RAMs and a summary of their key findings, advantages, and disadvantages are provided in Table 3.

\section{Khorana Risk Score (KRS)}

KRS was developed in 2008 with a cohort of around 4000 ambulatory cancer patients. Two-thirds of the population was included in the derivation of the score, and then the remaining one-third was used to validate it. Median follow-up was 73 days only. The score was composed of the tumour site, patient body mass index, and pre-chemotherapy blood counts. Throughout the last decade, numerous amounts of validation trials were performed. Some were disease-specific such as Srikanthan et al for germ cell tumour, ${ }^{30}$ and Santai et al, who did pooled analysis for lymphoma. ${ }^{31}$ In 2019 , Mulder et al enrolled 34,555 from 55 cohorts of ambulatory cancer patients assessing the six-month incidence of thrombosis and KRS performance in a systematic review and metaanalysis. The authors concluded that KRS could be used to select cancer patients at high VTE risk for thromboprophylaxis; however, most CAT events take place outside this high-risk group. ${ }^{11}$ It was also noted that reducing the threshold of KRS score to two points was 
Table 3 RAM in Solid Organ Malignancy; Populations, Statistics, Advantages, and Disadvantages

\begin{tabular}{|c|c|c|c|c|c|c|}
\hline RAM (Year) & Population & Type of Malignancy & Parameters & $\begin{array}{l}\text { C Statistics/ } \\
\text { HR }\end{array}$ & $\begin{array}{l}\text { Validation } \\
\text { Cohort }\end{array}$ & $\begin{array}{l}\text { Advantages/ } \\
\text { Disadvantages }\end{array}$ \\
\hline $\begin{array}{l}\text { Khorana risk } \\
\text { score }(2008)^{16}\end{array}$ & $\begin{array}{l}\text { Derivation } \\
\text { cohort, } \mathrm{n}= \\
270 \mid \\
\text { Validation } \\
\text { cohort, } \mathrm{n}= \\
1365\end{array}$ & $\begin{array}{l}\text { Breast, Lung, Ovarian, } \\
\text { Sarcoma, Colon, and } \\
\text { Lymphomas }\end{array}$ & $\begin{array}{l}\text { Site of cancer platelet } \\
\text { count } \geq 350 \times 10^{9} / \mathrm{L} \\
\text { haemoglobin } \leq 100 \mathrm{~g} / \mathrm{L} \mathrm{(10} \\
\mathrm{g} / \mathrm{dL}) \text { and } / \text { or use of } \\
\text { erythropoiesis-stimulating } \\
\text { agents, leukocyte count } \\
\geq 1 \mathrm{I} \times 10^{9} / \mathrm{L} \text {, body mass } \\
\text { index }(\mathrm{BMI}) \text { of } 35 \mathrm{~kg} / \mathrm{m} 2 \\
\text { or more }\end{array}$ & $\begin{array}{l}0.7 \text { for both } \\
\text { cohorts }\end{array}$ & $\begin{array}{l}\text { More than } 55 \\
\text { validation } \\
\text { cohorts and } \\
\text { several } \\
\text { systematic } \\
\text { reviews. }\end{array}$ & $\begin{array}{l}\text { Advantages: } \\
\text { Good in } \\
\text { classifying high- } \\
\text { risk. } \\
\text {-more } \\
\text { predictive when } \\
\text { considering } \\
\text { a score of } \geq 2 \text { as } \\
\text { a cut-off point } \\
\text { for high risk } \\
\text { Disadvantages: } \\
\text { Suboptimal } \\
\text { performance in } \\
\text { predicting VTE } \\
\text { in low-risk } \\
\text { groups }\end{array}$ \\
\hline $\begin{array}{l}\text { Vienna Cancer } \\
\text { and } \\
\text { Thrombosis } \\
\text { Study (CATS) } \\
\text { Score }(2018)^{17}\end{array}$ & $n=819$ & $\begin{array}{l}\text { Breast, Lung, Stomach, } \\
\text { Colorectal, Pancreas, } \\
\text { Kidney, Prostate, Brain, } \\
\text { Lymphoma, Multiple } \\
\text { myeloma }\end{array}$ & $\begin{array}{l}\text { Adds soluble P-selectin } \\
\text { and D-dimer to KRS }\end{array}$ & $\begin{array}{l}\text { I.9 per I point } \\
\text { increase }\end{array}$ & $\begin{array}{l}\text { Comparison } \\
\text { study with no } \\
\text { statistical } \\
\text { significance }^{2 *}\end{array}$ & $\begin{array}{l}\text { Disadvantages: } \\
\text { Applicability in } \\
\text { P soluble } \\
\text { monitoring in } \\
\text { a real-life setting } \\
\text { might not be } \\
\text { feasible }\end{array}$ \\
\hline $\begin{array}{l}\text { New Vienna } \\
\text { (CATSCORE) }^{18}\end{array}$ & $\begin{array}{l}\text { CATS } \\
\text { cohort, } n= \\
1423 \\
\text { MICA } \\
\text { cohort, } n= \\
832\end{array}$ & $\begin{array}{l}\text { Breast, Prostate, Lung, } \\
\text { Colorectal, Esophagus, } \\
\text { Kidney, Lymphoma, } \\
\text { Bladder or urothelial, } \\
\text { Uterine, Cervical, } \\
\text { Ovarian, Pancreas, } \\
\text { Stomach }\end{array}$ & $\begin{array}{l}\text { Site of cancer and } \\
\text { D-dimer }\end{array}$ & $\begin{array}{l}0.66 \text { in CATS } \\
0.68 \text { in MICA }\end{array}$ & $\begin{array}{l}\text { Comparison } \\
\text { study with no } \\
\text { statistical } \\
\text { significance }^{2 *}\end{array}$ & $\begin{array}{l}\text { Advantages: } \\
\text { only two factors } \\
\text { score } \\
\text { Disadvantage: } \\
\text { Suboptimal } \\
\text { performance in } \\
\text { the comparison } \\
\text { trial }\end{array}$ \\
\hline $\begin{array}{l}\text { PROTECHT } \\
\text { Score (20I2) }\end{array}$ & $\begin{array}{l}\text { Placebo } \\
\text { arm, } n= \\
381 \\
\text { Nadroparin } \\
\text { arm, } n= \\
769\end{array}$ & $\begin{array}{l}\text { Gastrointestinal, Lung, } \\
\text { Breast, Ovary, } \\
\text { Pancreas, Head and } \\
\text { Neck }\end{array}$ & $\begin{array}{l}\text { Add gemcitabine, } \\
\text { cisplatin, or carboplatin } \\
\text { therapy to KRS }\end{array}$ & NA & $\begin{array}{l}\text { I study with } \\
\text { positive }^{19} \\
2 \text { studies show } \\
\text { poor } \\
\text { performance } \\
2,20\end{array}$ & $\begin{array}{l}\text { Advantages: } \\
\text { easy to use, } \\
\text { considers } \\
\text { treatment- } \\
\text { related risk } \\
\text { factors } \\
\text { Disadvantages: } \\
\text { Suboptimal } \\
\text { performance in } \\
\text { the comparison } \\
\text { trial }\end{array}$ \\
\hline $\begin{array}{l}\text { CONKO004 } \\
(2015)^{21}\end{array}$ & $n=312$ & NA & $\begin{array}{l}\text { Replace BMI in KRS with } \\
\text { performance status }\end{array}$ & NA & $\begin{array}{l}\text { Two } \\
\text { comparison } \\
\text { study with } \\
\text { negative } \\
\text { outcome*19,20 }\end{array}$ & $\begin{array}{l}\text { Advantage: easy } \\
\text { applicability } \\
\text { Disadvantages: } \\
\text { poor } \\
\text { stratification } \\
\text { performance }\end{array}$ \\
\hline
\end{tabular}

(Continued) 
Table 3 (Continued).

\begin{tabular}{|c|c|c|c|c|c|c|}
\hline RAM (Year) & Population & Type of Malignancy & Parameters & $\begin{array}{l}\text { C Statistics/ } \\
\text { HR }\end{array}$ & $\begin{array}{l}\text { Validation } \\
\text { Cohort }\end{array}$ & $\begin{array}{l}\text { Advantages/ } \\
\text { Disadvantages }\end{array}$ \\
\hline $\begin{array}{l}\text { ONKOTEV } \\
\text { Score }(2017)^{22}\end{array}$ & $n=843$ & & $\begin{array}{l}\text { Khorana score }>2 \text {, } \\
\text { personal history of VTE, } \\
\text { metastatic disease, } \\
\text { vascular/lymphatic } \\
\text { macroscopic } \\
\text { compression }\end{array}$ & $\begin{array}{l}\text { C-statistic: } 0.719 \\
\text { at } 3 \text { months } \\
0.754 \text { at } 6 \\
\text { months } \\
\text { HR: Score = I: } \\
3.29 \\
\text { Score }=2: 6.54 \\
\text { Score }>2: 13.74\end{array}$ & $\begin{array}{l}\text { Multiple } \\
\text { validation and } \\
\text { comparison } \\
\text { trials with } \\
\text { negative } \\
\text { outcome.*2,20 }\end{array}$ & $\begin{array}{l}\text { Advantages: } \\
\text { easy to apply, } \\
\text { consider } \\
\text { tumour-related } \\
\text { factors } \\
\text { Disadvantages: } \\
\text { Suboptimal } \\
\text { performance }\end{array}$ \\
\hline $\begin{array}{l}\text { The } \\
\text { COMPASS- } \\
\text { CAT score } \\
(2016)^{23}\end{array}$ & $\mathrm{n}=1023$ & $\begin{array}{l}\text { Breast, Colorectal, } \\
\text { Lung, or Ovarian cancer }\end{array}$ & $\begin{array}{l}\text { Anthracycline or anti- } \\
\text { hormonal therapy, time } \\
\text { since cancer diagnosis, } \\
\text { central venous catheter, } \\
\text { stage of cancer, presence } \\
\text { of cardiovascular risk } \\
\text { factors, recent } \\
\text { hospitalization for acute } \\
\text { medical illness, personal } \\
\text { history of VTE, and } \\
\text { platelet count }\end{array}$ & C statistic: 0.850 & $\begin{array}{l}\text { Multiple } \\
\text { validation. }^{24-27}\end{array}$ & $\begin{array}{l}\text { Advantages: } \\
\text { Good } \\
\text { performance in } \\
\text { lung } \\
\text { carcinoma, }{ }^{24} \\
\text { moves from } \\
\text { traditional KRS } \\
\text { Disadvantages: } \\
\text { poor } \\
\text { calibration. }\end{array}$ \\
\hline $\begin{array}{l}\text { Tic-ONCO } \\
\text { score }(2018)^{28}\end{array}$ & $n=391$ & & $\begin{array}{l}\text { Adds genetic risk score } \\
\text { to KS }\end{array}$ & $\begin{array}{l}\text { C-statistic } 0.73 \\
H R=1.69\end{array}$ & NA & $\begin{array}{l}\text { Disadvantages: } \\
\text { Application of } \\
\text { genetics in } \\
\text { a real-life setting } \\
\text { is questionable }\end{array}$ \\
\hline $\begin{array}{l}\text { The MDACC } \\
\text { CAT model }{ }^{29}\end{array}$ & $n=548$ & $\begin{array}{l}\text { Breast, Gastrointestinal } \\
\text { non-pancreas, Pancreas, } \\
\text { Genitourinary non- } \\
\text { kidney Kidney, } \\
\text { Gynaecological Lung } \\
\text { and head/neck } \\
\text { Lymphoma }\end{array}$ & $\begin{array}{l}\text { Presence of metastasis, } \\
\text { use of platinum-based } \\
\text { chemotherapy, the use of } \\
\text { ESAs and malignancies of } \\
\text { origin in the } \\
\text { gastrointestinal, } \\
\text { gynecologic, and head- } \\
\text { neck/lung organs }\end{array}$ & C-index: 0.74 & NA & $\begin{array}{l}\text { Advantages: } \\
\text { readily available } \\
\text { information } \\
\text { Disadvantages: } \\
\text { lack of external } \\
\text { validation }\end{array}$ \\
\hline
\end{tabular}

Notes: *Comparison studies was done between Khorana, PROTECHT, CONKO, CATScore and ONKOTEV.

Abbreviations: MICA, Multinational Cohort Study; CATS, Vienna Cancer and thrombosis study; HR, hazards ratio; C-statistic /C-index, concordance statistic; NA, not available.

able to stratify $55 \%$ of CAT patients as high risk compared to $23 \%$ for a threshold of $\geq 3$ points. Overall, KRS was able to classify high-risk patients; however, predicting CAT in the low-risk groups is suboptimal. Notably, KRS performance in predicting VTE in specific subtypes of malignancies is less than others, such as lung carcinoma, ${ }^{32}$ urothelial malignancy, ${ }^{33}$ and hepatocellular carcinoma. $^{34}$ Despite the limitation of KRS in a pooled analysis of the recent CASSINI and AVERT studies, comparing direct oral anticoagulant (DOAC) thromboprophylaxis to placebo, thromboprophylaxis with
DOAC in patients with $\mathrm{KRS} \geq 2$ favours a 6-month VTE risk decrement of 0.56 (95\% CI $0.35-0.89){ }^{5,35-37}$

Vienna Cancer and Thrombosis Study (CATS) Score Ay, et al developed a VTE-risk evaluation tool in the Vienna-Cancer and Thrombosis study (Vienna-CATS). It integrated high D-dimer and P-selectin levels to Khorana score after validating their significant predictive value in an individual cohort. The six-month VTE risk was $17.7 \%$ in the high-risk group ( $\geq 3$ points). This score's positive predictive value PPV was higher than the Khorana score; 
however, clinical utilization is constrained by the need for particular biomarkers, such as P-selectin. ${ }^{17,38}$

\section{New Vienna (Catscore)}

The same research group of Vienna-CATS score published a new score with 1423 derivation cohort and 832 patients for the validation cohort. The score comprises only two items: D-dimer and tumour site levels before chemotherapy developing a nomogram to predict CAT. It reported better c-indexes over the Khorana score in derivation $(0.66$ vs 0.61$)$ and validation ( 0.68 vs 0.56$)$ cohorts. Nevertheless, the applicability of its use in a real-life setting has to be considered. ${ }^{18}$

\section{PROTECHT Score}

It has been suggested to add gemcitabine, cisplatin, or carboplatin therapy as additional risk factors to KRS by Verso et al in 2012, based on data analysis from the PROTECHT study. The Protecht score showed an enhanced capacity to identify patients at high risk for VTE compared to the Khorana score. ${ }^{39,40}$ The performance of the Protecht score was assessed in several RAM comparison trials. Van Es et al in 2017 reported that the score appears to distinguish better between lowand high-risk patients compared to KRS and CONKO scores. However, another two studies by Schorling et al and Di Nisio et al concluded that the score performed suboptimally at the conventional 3-point threshold. ${ }^{2,19,20}$

\section{CONKO004 Score}

A modification of the Khorana score by substituting BMI with performance status was suggested by Pelzer et al in the CONKO004 study evaluating the use of LMWH prophylaxis in pancreatic cancer patients. This score has been included in two comparison studies with no positive outcome. ${ }^{19-21}$

\section{ONKOTEV Score}

A Khorana modification score considers adding vascular structures compression, the presence of metastatic disease, and the personal history of previous VTE. In a validation cohort $(n=843)$, the 12-months VTE probability was $33.9 \%$ among patients with a score $\geq 3$ and $19.4 \%$ in patients with a score of 2 . The AUC was reported superior for ONKOTEV than the Khorana score at six months $(0.75$ vs 0.59$){ }^{22}$ This score has undergone further validations in a retrospective study with pancreatic cancer cohort only. It showed a cumulative prevalence of CAT was less than $10 \%$ for ONKOTEV scores 0 or 1 and approximately
$40 \%$ and $70 \%$ for scores 2 and $\geq 3$, respectively. ${ }^{41}$ Subsequently, another study by Di Nisio et al concluded that performance improves at a positivity threshold of two points instead of three. Two studies by Schorling et al and Van Es et al concluded the RAM failed to show statistical significance in predicting VTE. ${ }^{2,19,20}$ ONKOTEV score is easily applicable and have good predictability in a score of 2 and more and offers better stratification than KRS however shares the same limitation of failing to identify cases in the low-risk group.

\section{The COMPASS-CAT Score}

The COMPASS-CAT score was developed to improve CAT risk assessment for colon, lung, ovarian, and breast cancers. This score includes cancer-associated factors (time since diagnosis, stage), patient-related characteristics (cardiovascular risk factors, platelet count, history of VTE, recent hospitalization), and treatment-associated aspects (anthracycline or anti-hormonal therapy, central venous catheter). The risk of VTE was $1.7 \%$ in the low/intermediate-risk group, while in the high-risk population, it was $13.3 \%$. The score had a good discriminatory capacity (AUC 0.85). ${ }^{23}$ Retrospective validation of 3814 patients concluded that model discrimination was moderate and calibration was poor; however, the model had a good negative predictive value. ${ }^{27}$ On the contrary, two validation studies involving lung carcinoma patients showed good outcomes, which will be discussed later in this work.

\section{The MDACC CAT Model}

University of Texas MD Anderson Cancer Center developed a new RAM Using multivariate model analyses. The presence of metastatic disease, platinum-based chemotherapy regime, ESAs use, and malignancies of origin in the gastrointestinal, gynecologic, and head-neck/lung organs were thrombosis determinants used to construct a nomogram for CAT prediction. The c-index of the model was 0.74 indicating good discrimination. There is no external validation of this nomogram yet. ${ }^{29}$

\section{TiC-Onco Risk Score}

TiC-Onco is unique from other RAMs as it included genetic risk factors after three steps development protocol. It is composed of Genetic risk, BMI $>25$, Family history, and Primary tumour site. The study showed a positive predictive value of up to $37 \%$, which is only an incremental increase over the predictive values obtained after using the Khorana score that correctly predicted VTE in only $22 \%$ of the CAT patients. It was not validated yet, 
and the applicability in the real-life setting is guarded by the diagnostic capacity of a genetic lab in different hospitals. $^{28}$

\section{Risk Assessment Models in Lung Carcinoma}

Lung carcinoma is a distinctive group of solid organ malignancy given the disease nature and the proximity to major vessels and treatment protocols. Lung cancer has been associated with a high incidence of VTE compared to other malignancy groups; this led to more research in this subgroup of patients. ${ }^{42,43}$ Table 4 shows several RAMs were studied explicitly for lung carcinoma with a total population of 4161 patients.

\section{Khorana Risk Score}

A meta-analysis evaluated 3293 patients, of which 1913 were lung cancer patients. In the analysis, the Khorana score was incapable of stratifying patients with lung cancer based on their VTE risk compared to other malignancy groups. ${ }^{44}$ A prospective study by Mansfield et al for nonsmall cell lung carcinoma confirmed the limitation of KRS in stratifying patients according to their VTE risk ${ }^{32}$ similar to a comparison study by Rupa-Matysek et al. ${ }^{24}$

\section{Compass-Cat}

Despite the performance in the overall solid organ malignancy validation study, COMPASS-CAT score in lung carcinoma in specific has a superiority study in which Rupa-Matysek et al; compared Khorana risk score (KRS), COMPASS-cancer associated thrombosis score (COMPASS-CAT), PROTECHT score and CONKO score. Moreover, it involved 118 patients with lung cancer. The COMPASS-CAT model was the most precise predictor of VTE incidence in patients with lung malignancy with a $\mathrm{C}$ statistic of 0.89 . The score was able to detect $100 \%$ of patients with established VTE.

\section{ROADMAP-CAT Biomarker Score}

The prospective ROADMAP-CAT study detected two biomarkers of hypercoagulability, the mean rate index (MRI) of the propagation phase of thrombin generation and the procoagulant phospholipid-dependent clotting time (Procoag-PPL). These have been clinically significant for stratifying ambulatory cancer patients with lung

Table 4 Different RAM in Lung Carcinoma Components, Statistics, and Performances

\begin{tabular}{|c|c|c|c|c|c|}
\hline RAM & KRS $^{16}$ & COMPASS-CAT ${ }^{23}$ & $\begin{array}{l}\text { ROADMAP-CAT } \\
\text { Biomarker Score }^{26}\end{array}$ & $\begin{array}{l}\text { COMPASS- } \\
\text { CAT ROADMAP }\end{array}$ & $\begin{array}{l}\text { CANTARISK } \\
\text { Score }^{54}\end{array}$ \\
\hline Parameters & $\begin{array}{l}\text { Site of cancer platelet } \\
\text { count } \geq 350 \times 109 / \mathrm{L} \\
\text { haemoglobin } \leq 100 \mathrm{~g} / \mathrm{L} \\
(10 \mathrm{~g} / \mathrm{dL}) \text { and } / \text { or use of } \\
\text { erythropoiesis } \\
\text { stimulating agents, } \\
\text { leukocyte count } \geq 1 \text { I } \\
\times 10^{9} / \mathrm{L} \text {, body mass } \\
\text { index of } 35 \mathrm{~kg} / \mathrm{m}^{2} \text { or } \\
\text { more }\end{array}$ & $\begin{array}{l}\text { Anthracycline or anti- } \\
\text { hormonal therapy, time } \\
\text { since cancer diagnosis, } \\
\text { central venous catheter, } \\
\text { stage of cancer, } \\
\text { presence of CV risk } \\
\text { factors platelet count, } \\
\text { recent hospitalization of } \\
\text { acute medical illness, } \\
\text { personal VTE history }\end{array}$ & $\begin{array}{l}\text { The procoagulant } \\
\text { phospholipid- } \\
\text { dependent clotting } \\
\text { time (Procoag-PPL) and } \\
\text { the mean rate index } \\
\text { (MRI) of the } \\
\text { propagation phase of } \\
\text { thrombin generation } \\
\text { assay }\end{array}$ & $\begin{array}{l}\text { Procoag- PPL and } \\
\text { MRI with the } \\
\text { COMPASS-CAT } \\
\text { RAM }\end{array}$ & $\begin{array}{l}\text { Older age, current or } \\
\text { former smokers, } \\
\text { chronic obstructive } \\
\text { pulmonary disease, } \\
\text { ECOG PS } \geq 2 \text {, no prior } \\
\text { cancer surgery, and } \\
\text { metastatic disease are } \\
\text { predictive of VTE }\end{array}$ \\
\hline Type & Pan cancerous & $\begin{array}{l}\text { Breast, Colorectal, Lung } \\
\text { or Ovarian cancer }\end{array}$ & Lung & Lung & Lung \\
\hline Statistics & $\begin{array}{l}\text { Unable to stratify (I.I; } \\
95 \%-\mathrm{Cl}, 0.72-\mathrm{I} .7)^{44}\end{array}$ & C statistic $0.89^{24}$ & $\begin{array}{l}\text { (NPV) } 97 \% \\
\text { (PPV) } 25 \%\end{array}$ & $\begin{array}{l}\text { (NPV) } 97 \% \\
\text { (PPV) } 70 \%\end{array}$ & $\begin{array}{l}\mathrm{P}<0.000 \mathrm{I} \\
\text { awaiting validation }\end{array}$ \\
\hline Performance & $\begin{array}{l}\text { KRS underperformed in } \\
\text { risk stratification in lung } \\
\text { ca. }\end{array}$ & $\begin{array}{l}\text { Excellent performance } \\
\text { in small cohort, need } \\
\text { large cohort validation }\end{array}$ & $\begin{array}{l}\text { Applicability of special } \\
\text { blood assays in real life } \\
\text { setting need to be } \\
\text { considered }\end{array}$ & $\begin{array}{l}\text { Applicability of } \\
\text { special blood assays } \\
\text { in real life setting } \\
\text { need to be } \\
\text { considered }\end{array}$ & Need a validation \\
\hline
\end{tabular}

Abbreviations: $\mathrm{Cl}$, concordance index; C- statistic, concordance statistic; NPV, negative predictive value; PPV, positive predictive value; ECOG PS, Eastern Cooperative Oncology Group Performance Status. 
adenocarcinoma who had received a maximum of one chemotherapy cycle into high and intermediate/low risk for VTE. This score's positive predictive value (PPV) was $25 \%$, and the negative predictive value (NPV) was $97 \%{ }^{26}$

In the same study, the research team studied the association of the Procoag- PPL and MRI with the COMPASS-CAT RAM, which added to its accuracy with PPV of $70 \%$ and NPV of $97 \%$. Although this result is promising, the ProcoagPPL and MRI testing feasibility in the real-life setting as a standard of care in all cancer patients is questionable.

\section{CANTARISK Score}

In a retrospective analysis of 1980 patients with lung cancer, the study concluded that current or former smokers, older age, chronic obstructive pulmonary disease, ECOG PS $\geq 2$, no prior cancer surgery, and metastatic disease are predictive of VTE in lung carcinoma patients; however, a validation study is required.

\section{Testicular Germ Cell Tumour}

Testicular germ cell tumours are among the most common malignancies affecting adolescents and young adults. ${ }^{45}$ In this group of malignancy, thrombosis events cover up to $8.4 \%$ and increase to $17 \%$ in patients ongoing cisplatinbased chemotherapy, ${ }^{45,46}$ hence some research was directed to thrombosis risk assessment.

Aside from the pancancerous KRS, two risk assessment model was developed:

\section{Srikanthan et al RPLN-VTE-Risk-Classifier}

A single parameter risk identifier by Srikanthan et al in a cohort of 216 patients concluded that large retroperitoneal lymphadenopathy (RPLN) more than $5 \mathrm{~cm}$ with metastatic disease in patients receiving first-line cisplatin-based chemotherapy is associated with high thrombosis risk (AUROC 0.61 vs 0.57 for KRS). ${ }^{30}$

\section{Bezan et al Risk Assessment Model}

In derivation cohort 657 and validation cohort 349, Bezan et al. developed a disease-specific RAM. The findings underpinned higher tumour stage and a large RPLN as the significant predictors of VTE. The score has good risk discrimination in comparison to the previously mentioned RPLN-VTE risk classifier (AUC-ROC:0.75 vs.0.63). ${ }^{46}$

\section{Risk Assessment Model in Hematological Malignancies}

Patients with haematological malignancy tend to be underrepresented groups in thrombosis research since this population incline to have variable characteristics and blood parameters. Also, this group of patients remains vulnerable to thrombosis predisposed by potentially thrombogenic therapy. Several works aimed to construct risk assessment models (RAM) to guide patients' risk stratification and treatment. Noticeably, lymphoma and multiple myeloma have more RAM-related research in comparison to acute leukaemia. ${ }^{47}$ Summary of the RAMs categorized under each haematological malignancy with a total population of 20,383 patients, and their performance is provided in Table 5.

\section{Acute Leukaemia}

A misconception that thrombosis risk in patients with leukaemia was lower than that of solid tumours ${ }^{48}$ is being replaced by recent studies which showed the incidence of thrombosis to be similar or even higher than in those with solid tumours. ${ }^{49}$

The prevalence of thrombosis in acute myelocytic leukemia (AML) varies. In a cohort of 5394 cases, the largest cohort of AML, the 2-year cumulative incidence of deep vein thrombosis and/or pulmonary embolism was $5.2 \%{ }^{47}$ While acute promyelocytic leukemia (APL), the incidence of thrombosis increases to 10 $15 \%$ compared to other types of acute myeloid leukaemia due to distinct molecular, morphologic, clinical characteristics, procoagulant and fibrinolytic properties of pathological promyelocytes. ${ }^{50}$

In acute lymphocytic leukemia (ALL), a study conducted by $\mathrm{Ku}$ et al among 2482 cases with ALL, the 2-year incidence of VTE was 4.5\%. Also, as reported by Grace et al, the ratio could increase to $42 \%$ in adults with ALL during chemotherapy. ${ }^{51,52}$ This significantly increased risk is attributed to asparaginase and central venous catheters, being major risk factors for thrombosis in ALL. Other risk factors are older age and the number of chronic comorbidities. ${ }^{51,53}$

Risk assessment models in leukemia are as follows:

\section{Khorana Score}

In a study conducted by Mirza et al, 867 AML patients were included from 2000 to 2018 . There was no statistically significant increment in the risk of thrombosis associated with a higher KRS in AML patients with a KRS of 1 to 3 . Of notice, only a few patients were found to have a KRS $>3$. This was mainly due to cytopenias that are common in AML. Therefore, Khorana was not the optimum risk score for AML. ${ }^{55}$ 
Table 5 RAM in Haematological Malignancies; Cohort and Performance

\begin{tabular}{|c|c|c|c|}
\hline RAM & Subtype & No & Performance \\
\hline \multicolumn{4}{|l|}{ Leukaemia } \\
\hline $\mathrm{KRS}^{55}$ & AML & $867 \mathrm{AML}$ & Suboptimal performance $(P=0.19)$ \\
\hline ISTH-DIC ${ }^{8}$ & AML/APL & $\begin{array}{l}272 \text { (adult) }+132 \text { (elderly) AML/ } \\
63 \mathrm{APL}\end{array}$ & Good performance, HR $4.79(1.7 \mathrm{I}-13.45) /(P=0.00 \mathrm{I})$. \\
\hline AL Ani et al score & AML/APL/ALL & 501 & $\begin{array}{l}\text { Good performance C-statistic of } 0.664 \text { ( } 95 \% \text { Cl: } 0.590- \\
0.738 \text { ) }\end{array}$ \\
\hline \multicolumn{4}{|l|}{ Lymphoma } \\
\hline $\mathrm{KRS}^{31}$ & $\begin{array}{l}\text { Multiple validation } \\
\text { studies }\end{array}$ & & Unable stratify low risk patients \\
\hline Throly score ${ }^{56,57}$ & All subtypes & $\begin{array}{l}1820 \text { (derivation) }+428 \\
\text { (validation) }\end{array}$ & Inadequate discrimination \\
\hline Hohaus el al. score ${ }^{58}$ & All subtypes & 857 & Identified $82 \%$ of VTE but needs validation \\
\hline TiC-Lympho 59 & All subtypes & 254 & AUC 0.783 ; however, a feasibility trial needed \\
\hline CATSCORE $^{18}$ & All subtypes & 249 in derivation & Needs validation \\
\hline \multicolumn{4}{|l|}{ Multiple myeloma (MM) } \\
\hline IMPEDE VTE ${ }^{60}$ score & MM & $\begin{array}{l}\text { Derivation } 4446 \\
\text { Validation } 4256\end{array}$ & $\begin{array}{l}\text { Good performance } \\
\text { outperformed the current IMWG/NCCN guidelines }(\mathrm{p}< \\
0.000 \mathrm{I})\end{array}$ \\
\hline SAVED Score ${ }^{61}$ & MM & $\begin{array}{l}\text { Derivation (2397) validation } \\
(125 I)\end{array}$ & Good performance $(p<0.01)$ \\
\hline $\begin{array}{l}\text { ROADMAP-CAT-MM } \\
\text { score }^{62}\end{array}$ & MM & 144 & Good performance, Feasibility validation trial required \\
\hline $\mathrm{KRS}^{60}$ & MM & 2874 & Poor prediction value c-statistic 0.52 \\
\hline
\end{tabular}

\section{Al-Ani et al Risk Assessment Rule}

A risk assessment model was developed by Al-Ani et al in a cohort of 501 leukemia patients, of these, 74 were having ALL. It is a simple score with three components, previous history of VTE (three points), ALL (two points) and platelet count $>50 \times 109$ (one point). A score of three and more indicates a high risk. The score is statistically significant with a C-statistic of 0.664 (95\% CI: 0.590 0.738 ) and ongoing external validation. ${ }^{49}$

\section{International Society on Thrombosis and Haemostasis Disseminated Intravascular Coagulation Score (ISTH DIC)}

The score which was initially derived for DIC risk assessment was investigated in a prospective study in a cohort of 272 adult patients by Libourel et al, and it was noted that it significantly predicted arterial and venous thrombosis with a hazard ratio (HR) for a high DIC score $(\$ 5)$ of 4.79 (1.7113.45). ${ }^{63}$ A validation cohort of 132 elderly patients with AML confirmed the finding (HR 11.08 [3.23-38.06]). ${ }^{63}$ D-dimer levels were the most predictive for thrombosis. This study excluded APL, which is highly associated with DIC. In another cohort by Mitrovic et al, 63 consecutive de novo APL patients were included. Thrombosis events were reported in 13 cases (20.6\%). Initial ISTH DIC score was predictive for venous TE $(\mathrm{P}=0.001) .{ }^{50}$ However, in a study by Al-Ani et al, the parameters were not predictive of thrombosis, but that study lacked D-dimer level sampling. ${ }^{49}$ Table 6 present the parameters and their assigned scores for the ISTH DIC score.

\section{Lymphoma}

Lymphomas are the most prevalent haematological malignancies globally and at higher VTE risk than different 
Table 6 ISTH DIC Score

\begin{tabular}{|c|c|c|}
\hline Variable & Value & Points \\
\hline Platelet count & $\begin{array}{l}>100 \times 109 / \mathrm{L} \\
>50-<100 \times 109 / \mathrm{L} \\
<50 \times 109 / \mathrm{L}\end{array}$ & $\begin{array}{l}0 \text { Points } \\
\text { I Points } \\
2 \text { Points }\end{array}$ \\
\hline INR & $\begin{array}{l}<1.3 \\
1.3-1.7 \\
>1.7\end{array}$ & $\begin{array}{l}0 \text { Points } \\
\text { I Points } \\
2 \text { Points }\end{array}$ \\
\hline D-dimer & $\begin{array}{l}<400 \\
400-4000 \\
>4000\end{array}$ & $\begin{array}{l}0 \text { Points } \\
\text { I Points } \\
2 \text { Points }\end{array}$ \\
\hline Fibrinogen level & $\begin{array}{l}>1.0 \mathrm{~g} / \mathrm{L} \\
<1.0 \mathrm{~g} / \mathrm{L}\end{array}$ & $\begin{array}{l}0 \text { Points } \\
\text { I Point }\end{array}$ \\
\hline
\end{tabular}

cancer types, particularly solid tumours. ${ }^{64}$ Aggressive lymphomas occur in $10-15 \%$ incidence of CAT in the first year of diagnosis. ${ }^{65}$ Hodgkin lymphoma (HL) accounts for nearly $10 \%$ of all lymphomas. Thrombosis events vary from $5.0 \%$ to $59.5 \%$ in lymphomas and are more significant in non-Hodgkin than in HL. ${ }^{66}$ As with other haematological malignancies, anticoagulation for treatment or prophylaxis is challenging because of the thrombocytopenia, which is either disease-related or treatment-related. In the recent Cassini trial that compared rivaroxaban $10 \mathrm{mg}$ once-daily versus placebo for prophylaxis of outpatients with Khorana score $(\geq 2)$ receiving chemotherapy, $7 \%$ were lymphoma cases. The findings showed reductions of approximately $60 \%$ of thrombotic events. ${ }^{36}$ Risk assessment models for thrombosis risk in lymphoma are more than other haematological malignancies. Examples of RAMs for lymphoma are as follows:

\section{Khorana Score}

In the initial cohort during the development of the score, $12.6 \%$ had lymphomas. Subsequently, several studies have specifically studied KRS in lymphoma. The majority of them concluded that the KRS did not adequately predict VTE events in patients at a higher VTE risk. However, in a pooled analysis of 12 lymphoma studies by Santi et al, the findings showed that a Khorana score of 3 and more was associated with VTE incidence. ${ }^{31}$ Later, several Khorana modification scores were developed; however, lymphoma patients were not represented. ${ }^{65,67,68}$

\section{Thrombosis Lymphoma- ThroLy Score}

ThroLy is a disease-specific RAM developed by Antic et al, as shown in Table 7. The study population was 1820 lymphoma patients. The model produced a negative predictive value of $98.5 \%$, a positive predictive value of $25.1 \%$, a sensitivity of $75.4 \%$, and a specificity of $87.5 \%$. A high-risk score had a positive predictive value of $65.2 \% .{ }^{69}$ However, a validation study by Rupa-Matysek et al with 428 patients retrospectively concluded that the ThroLy score was not the most accurate model for predicting CAT in a high-risk population where $48 \%$ of VTE occurred in the low-risk group. ${ }^{57}$ In another validation study by Onur Kirkizlar et al involved a cohort of 150 adult patients with HL; the results raise the same issue of inadequacy of discrimination of the risk groups where nearly one-half of the VTE incident was in the low ThroLy score. ${ }^{66}$

\section{Hohaus et al Score}

A simple risk assessment score was developed by Hohaus et al and investigated 857 adult patients with newly diagnosed lymphomas. It includes three factors, CNS disease, bulky mass, and performance status. The score recognized $82 \%$ of CAT in the high-risk patients, $48 \%$ of patients of the total population; however, this score needs further validation. ${ }^{58,65}$

\section{TiC-ONCO-Associated Lymphoma Score (TiC-Lympho)}

A lymphoma-specific RAM was developed as a variant of the TIC-ONCO score for solid organ tumours risk stratification. The F5 rs6025, F5 rs4524, F13 rs5985, SERPINA10 rs2232698, additionally some clinical variables (immobilization, Ann Arbor stage mediastinum extension, tumour type, and personal thrombotic history) were significantly related to CAT. The study found that incorporating genetic-clinical data to assess VTE risk is relevant to lymphoma. The predictive capacity for VTE in the lymphoma population exceeds that achieved by the Khorana and ThroLy scores. ${ }^{59}$ However, a validation study is required, especially to

Table 7 ThroLy Score

\begin{tabular}{|l|l|}
\hline Patient Characteristics & Assigned Score \\
\hline Previous VTE/acute myocardial infarction/stroke & 2 \\
Reduced mobility (ECOG 2-4), & $\mathrm{I}$ \\
Obesity (BMI $\left.>30 \mathrm{~kg} / \mathrm{m}^{2}\right)$ & 2 \\
Extranodal localization & $\mathrm{I}$ \\
Mediastinal involvement & 2 \\
Neutrophils $<1 \times 10^{9} / \mathrm{L}$ & $\mathrm{I}$ \\
Hemoglobin level $<100 \mathrm{~g} / \mathrm{L}$ & $\mathrm{I}$ \\
\hline
\end{tabular}


ascertain the applicability of using genetic parameters in a real-life setting.

\section{Cancer and Thrombosis Study (CATS) Score}

The CATS cohort included 249 patients with lymphoma (17\%), while the validation cohort of 832 patients did not contain lymphoma patients. It combined tumour-site category and D-dimer values to develop a simple RAM. Despite the statistical significance, a proper lymphoma validation cohort is required.

\section{Multiple Myeloma}

Multiple myeloma differs from other haematological malignancies by establishing recommendations in the existing 2014 international Myeloma Working Group (IMWG) guidelines and 2016 European Myeloma Network (EMN) guidelines that recommend standard risk stratification for MM patients on immunomodulatory drug-based therapy (IMiDs) ${ }^{70}$ The use of aspirin for low-risk patients and prophylactic dose LMWH for higher-risk patients is already recognized. However, the current evidence shows that the rate of VTE remains high, and a better risk tool is needed. ${ }^{70,71}$ Risk assessment scores for multiple myeloma are as follows:

\section{IMPEDE VTE Score}

Risk score in newly diagnosed multiple myeloma patients was developed by Sanfilippo et al in a cohort of 4446 using time-to-event analyses. It was then validated in a cohort of 4256 patients. VTE risk proportionally increased with the score (hazard ratio [HR], 1.20; $\mathrm{p}<$ 0.0001). Statistically, it outperformed the current IMWG/ NCCN guidelines; however, a real-life prospective validation is required before replacing this scoring system with the current guidelines. The RAM consists of (Immunomodulatory agent; Body Mass Index $\geq 25 \mathrm{~kg}$ / m2; Pelvic, hip, or femur fracture; Erythropoietin stimulating agent; Dexamethasone/Doxorubicin; Asian Ethnicity/ Race; VTE history; Tunnelled line/central venous catheter; Existing thromboprophylaxis). ${ }^{72}$

\section{SAVED Score}

A new RAM was developed in a separate analysis of older patients receiving IMiDs with a derivation population of 2397 and a validation study of 1251. It is a 5-point score that includes Asian ethnicity/race, prior surgery, age $\geq 80$ years, VTE history, and dexamethasone dose. It stratified around $30 \%$ of patients in both cohorts as high risk. HRs were $1.85(\mathrm{p}<0.01)$ and $1.98(\mathrm{p}<0.01)$ for high- versus low-risk groups in the derivation and validation cohorts, respectively, and similarly outperformed the guidelines. A prospective real-life cohort validation is needed. ${ }^{61}$

\section{ROADMAP-CAT-MM Score}

In a study involving 144 patients in a prospective risk assessment to detect patients with MM at risk for CAT, the findings demonstrated that longer Procoagulant phospholipid clotting time (Procoagulant-PPL) and lower endogenous thrombin potential (ETP) could significantly predict thrombosis. However, a powered study is required for validation.

\section{Khorana Score}

In a MM validation cohort that enrolled 2874 patients with a six month follow up, Khorana score failed to predict VTE accurately. ${ }^{60}$

\section{Conclusions and Practice Points}

The risk of venous thromboembolism VTE is up to 7-fold higher in cancer patients. ${ }^{2}$ Cancer-associated thrombosis (CAT) is the second prevalent cause of mortality in cancer patients. Thromboprophylaxis in ambulatory cancer patients is associated with a $50 \%$ decrement of CAT occurrence in a high-risk population, ${ }^{3}$ hence the need to stratify patients to high and low risk. Since 2008, numerous RAM has been developed.

In solid organ malignancy, to our knowledge, nine risk assessment scores were generated. The first and most known Khorana risk score still offers the best available risk assessment model when used with the threshold of 2 and above as a cut point for high-risk populations. ${ }^{11}$ However, KRS has two major limitations: failure to stratify low-risk patients and performing poorly in certain malignancy subtypes such as lung, urothelial, and haematological malignancies. ONKOTEV score is a Khorana score modification with better performance and easy applicability but shares the same limitation as KRS. ${ }^{41}$ The addition of genetic factors to stratify patients, although promising, is faced by the applicability restrains. ${ }^{28}$

The lung carcinoma population has a higher prevalence of thrombosis than other subtypes. The risk assessment model aims to stratify lung malignancy patients. The COMPASS-CAT score performed the best. ${ }^{24}$ If a large cohort trial confirmed the current finding, it should be used as a standard of care. In testicular germ cell tumour 
Bezan et al RAM is a validated good discriminatory RAM for this malignancy subtype. ${ }^{46}$

Cancer-associated thrombosis in haematological malignancy is under-investigated. Thrombosis in these subtypes has multiple confounding factors such as disease-related factors, eg, thrombocytopenia, and treatment-related factors like Treatment with 1 asparaginase. In acute leukaemia, Al-Ani et al developed a simple predictive tool that may be used as standard of care but is awaiting ongoing external validation. ${ }^{49}$ Despite the availability of different disease-specific scores in lymphoma-related thrombosis, in multiple myeloma, both SAVED and IMPEDED VTE scores performed better than currently used guidelines and can be used in risk stratification of patients with MM. $^{61,72}$

The guidelines already recommend the thromboprophylaxis of high-risk patients, given the significant reduction in mortality and morbidity. Using the KRS, which is already proved to have a substantial limitation, has considerably reduced the VTE burden. Therefore, a better RAM is likely to have a more favourable outcome. Meanwhile, the clinician knowledge and application remain limited mainly due to the lack of a standard score or easily accessible system that calculates different risks. We believe that the currently allocated risk factors might be sufficient to stratify the patient. Having a pan-cancerous score for all types of malignancy might be challenging to achieve because of the broad disease characteristics. The future research should be directed to focus on the applicability rather than derivation of new parameters that later on would be faced with the limitation of feasibility and availability in solid organ malignancy; we looked at the different RAM components, the similarities with one or two factors distinctive for each score. Some of these factors are very academic or not readily practised in the general clinical setting others easy applicable. We suggest using all these feasible and practical factors to create a new combined score that might have better sensitivity and specificity and has less limitation to have better RAM. Future research could be directed to examine the use of telemedicine applications to help in patients' risk stratification and treatment guidance considering the current changes in the healthcare delivery model imposed by the covid19 pandemic.

\section{Abbreviations}

CAT, cancer-associated thrombosis; RAM, risk assessment model; VTE, venous thromboembolism; PE, pulmonary embolism; KRS, Khorana risk score; DOAC, direct oral anticoagulant; BMI, body mass index; MM, multiple myeloma; HR, hazard ratio; ESA, erythrocyte stimulating agent; ECOG PS, Eastern Cooperative Oncology Group Performance Status; NNP, negative predictive value; PPV, Positive predictive value; OR, odds ratio; AML, acute myeloid leukaemia; APL, acute promyelocytic leukaemia; ALL, acute lymphoblastic leukaemia; NHL, non-Hodgkin lymphoma; HL, Hodgkin lymphoma; AUC, area under the curve.

\section{Ethics Statement}

This study did not require ethics approval.

\section{Disclosure}

The authors report no conflicts of interest in this work.

\section{References}

1. Mukai M, Oka T. Mechanism and management of cancer-associated thrombosis. J Cardiol. 2018;72(2):89-93. doi:10.1016/j.jjcc.2018.02. 011

2. Schorling RM, Pfrepper C, Golombek T, et al. Evaluation of biomarkers for the prediction of venous thromboembolism in ambulatory cancer patients. Oncol Res Treat. 2020;43(9):414-427. doi:10.1159/ 000508271

3. Fernandes CJ, Morinaga LTK, Alves JL, et al. Cancer-associated thrombosis: the when, how and why. Eur Respir Rev. 2019;28 (151):1-11. doi:10.1183/16000617.0119-2018

4. Khorana AA. Cancer and thrombosis: implications of published guidelines for clinical practice. Ann Oncol. 2009;20(10):1619-1630. doi:10.1093/annonc/mdp068

5. Rossel A, Robert-Ebadi H, Marti C. Preventing venous thromboembolism in ambulatory patients with cancer: a narrative review. Cancers. 2020;12(3):1-14. doi:10.3390/cancers 12030612

6. Kakkos SK, Arnaoutoglou E, Tsolakis IA, et al. Frequency and predictors of chemotherapy-associated venous thromboembolism: the prospective PREVENT study. Int Angiol. 2020;39(2):112-117. doi:10.23736/S0392-9590.20.04272-8

7. Khorana AA, Francis CW. Risk prediction of cancer-associated thrombosis: appraising the first decade and developing the future. Thromb Res. 2018;164(January):S70-S76. doi:10.1016/j.thromres.20 18.01.036

8. Barrett CD, Moore HB, Yaffe MB, Moore EE. ISTH interim guidance on recognition and management of coagulopathy in COVID-19: a comment. J Thromb Haemost. 2020;0-1. doi:10.1111/jth.14860

9. Key NS, Bohlke K, Falanga A. Venous thromboembolism prophylaxis and treatment in patients with cancer: ASCO clinical practice guideline update summary. $J$ Oncol Pract. 2019;15(12):661-665. doi:10.1200/JOP.19.00368

10. Khorana A, Kuderer NM, Culakova E, Lyman GH, Francis CW. Development and validation of a predictive model for chemotherapy- associated thrombosis. Blood. 2008;111(10):49 02-4907. doi:10.1182/blood-2007-10-116327

11. Mulder FI, Candeloro M, Kamphuisen PW, et al. The khorana score for prediction of venous thromboembolism in cancer patients: a systematic review and meta-analysis. Haematologica. 2019;104 (6):1277-1287. doi:10.3324/haematol.2018.209114 
12. Carrier M, Abou-Nassar K, Mallick R, et al. Apixaban to prevent venous thromboembolism in patients with cancer. $N$ Engl $\mathrm{J} \mathrm{Med}$. 2019;380(8):711-719. doi:10.1056/nejmoa1814468

13. Khorana AA, Soff GA, Kakkar AK, et al. Rivaroxaban for thromboprophylaxis in high-risk ambulatory patients with cancer. $N$ Engl J Med. 2019;380(8):720-728. doi:10.1056/nejmoa1814630

14. Arksey H, O'Malley L. Scoping studies: towards a methodological framework. Int J Soc Res Methodol Theory Pract. 2005;8(1):19-32. doi:10.1080/1364557032000119616

15. Levac D, Colquhoun H, O'Brien KK. Scoping studies: advancing the methodology. Implement Sci. 2010;5(69):1-9. doi:10.1017/ cbo9780511814563.003

16. Snyder PB, Groebner RJ, Leonard AW, Osborne TH, Wilson HR. Development and validation of a predictive model for. Phys Plasmas. 2009;16(5):4902-4908. doi:10.1063/1.3122146

17. Ay C, Dunkler D, Marosi C, et al. Prediction of venous thromboembolism in cancer patients. Blood. 2010;116(24):5377-5382. doi:10.1182/blood-2010-02-270116

18. Pabinger I, van Es N, Heinze G, et al. A clinical prediction model for cancer-associated venous thromboembolism: a development and validation study in two independent prospective cohorts. Lancet Haematol. 2018;5(7):e289-e298. doi:10.1016/S2352-3026(18)30063-2

19. van Es N, Di Nisio M, Cesarman G, et al. Comparison of risk prediction scores for venous thromboembolism in cancer patients: a prospective cohort study. Haematologica. 2017;102(9):1494-1501. doi:10.3324/haematol.2017.169060

20. Di Nisio M, van Es N, Rotunno L, et al. Long-term performance of risk scores for venous thromboembolism in ambulatory cancer patients. J Thromb Thrombolysis. 2019;48(1):125-133. doi:10.1007/ s11239-019-01845-6

21. Pelzer U, Opitz B, Deutschinoff G, et al. Efficacy of prophylactic low-molecular weight heparin for ambulatory patients with advanced pancreatic cancer: outcomes from the CONKO-004 trial. J Clin Oncol. 2015;33(18):2028-2034. doi:10.1200/JCO.2014.55.1481

22. Cella CA, Di Minno G, Carlomagno C, et al. Preventing venous thromboembolism in ambulatory cancer patients: the ONKOTEV Study. Oncologist. 2017;22(5):601-608. doi:10.1634/theoncologist.2016-0246

23. Gerotziafas GT, Taher A, Abdel-Razeq H, et al. A predictive score for thrombosis associated with breast, colorectal, lung, or ovarian cancer: the prospective COMPASS-Cancer-Associated Thrombosis Study. Oncologist. 2017;22(10):1222-1231. doi:10.1634/theoncologist.2016-0414

24. Rupa-Matysek J, Lembicz M, Rogowska EK, Gil L, Komarnicki M, Batura-Gabryel H. Evaluation of risk factors and assessment models for predicting venous thromboembolism in lung cancer patients. Med Oncol. 2018;35:5. doi:10.1007/s12032-018-1120-9

25. Gerotziafas GT, Spyropoulos AC, Syrigos K, et al. First external validation of the new COMPASS-CAT risk assessment model for ambulatory patients with breast, colorectal, lung or ovarian cancer. Thromb Res. 2018;164:S232. doi:10.1016/j. thromres.2018.02.111

26. Syrigos K, Grapsa D, Sangare R, et al. Prospective assessment of clinical risk factors and biomarkers of hypercoagulability for the identification of patients with lung adenocarcinoma at risk for cancer-associated thrombosis: the Observational ROADMAP-CAT Study. Oncologist. 2018;23(11):1372-1381. doi:10.1634/theoncologist.2017-0530

27. Spyropoulos AC, Eldredge JB, Anand LN, et al. External validation of a venous thromboembolic risk score for cancer outpatients with solid tumors: the COMPASS-CAT venous thromboembolism risk assessment model. Oncologist. 2020;25(7):1-8. doi:10.1634/theoncologist.2019-0482
28. Martín AJM, Ortega I, Font C, et al. Multivariable clinical-genetic risk model for predicting venous thromboembolic events in patients with cancer. $B r J$ Cancer. 2018;118(8):1056-1061. doi:10.1038/ s41416-018-0027-8

29. Rojas-Hernandez CM, Tang VK, Sanchez-Petitto G, Qiao W, Richardson M, Escalante C. Development of a clinical prediction tool for cancer-associated venous thromboembolism (CAT): the MD Anderson cancer center CAT model. Support Care Cancer. 2020;28 (8):3755-3761. doi:10.1007/s00520-019-05150-z

30. Srikanthan A, Tran B, Beausoleil M, et al. Large retroperitoneal lymphadenopathy as a predictor of venous thromboembolism in patients with disseminated germ cell tumors treated with chemotherapy. J Clin Oncol. 2015;33(6):582-587. doi:10.1200/ JCO.2014.58.6537

31. Santi RM, Ceccarelli M, Bernocco E, et al. Khorana score and histotype predicts incidence of early venous thromboembolism in non-Hodgkin lymphomas: a pooled-data analysis of 12 clinical trials of fondazione italiana linfomi (FIL). Thromb Haemost. 2017;117 (8):1615-1621. doi:10.1160/TH16-11-0895

32. Mansfield AS, Tafur AJ, Wang CE, Kourelis TV, Wysokinska EM, Yang P. Predictors of active cancer thromboembolic outcomes: validation of the Khorana score among patients with lung cancer. J Thromb Haemost. 2016;14(9):1773-1778. doi:10.1111/jth.13378

33. Tully CM, Apolo AB, Zabor EC, et al. The high incidence of vascular thromboembolic events in advanced urothelial cancer treated with platinum chemotherapy agents. Cancer. 2016;122(5):712. doi:10.1002/cncr.29801

34. Zhu Q, Li J, Yan JJ, Huang L, Wu MC, Yan YQ. Predictors and clinical outcomes for spontaneous rupture of hepatocellular carcinoma. World J Gastroenterol. 2012;18(48):7302-7307. doi:10. 3748/wjg.v18.i48.7302

35. Li A, Kuderer NM, Garcia DA, et al. Direct oral anticoagulant for the prevention of thrombosis in ambulatory patients with cancer: a systematic review and meta-analysis. J Thromb Haemost. 2019;17 (12):2141-2151. doi:10.1111/jth.14613

36. Khorana AA, Vadhan-Raj S, Kuderer NM, et al. Rivaroxaban for preventing venous thromboembolism in high-risk ambulatory patients with cancer: rationale and design of the CASSINI trial. Thromb Haemost. 2017;117(11):2135-2145. doi:10.1160/TH17-03-0171

37. Kimpton M, Wells PS, Carrier M. Apixaban for the prevention of venous thromboembolism in high-risk ambulatory cancer patients receiving chemotherapy: rational and design of the AVERT trial. Thromb Res. 2018;164(Suppl):S124-S129. doi:10.1016/j.thromres. 2018.01.018

38. Ay C, Simanek R, Vormittag R, et al. High plasma levels of soluble $\mathrm{P}$-selectin are predictive of venous thromboembolism in cancer patients: results from the Vienna Cancer and Thrombosis Study (CATS). Blood. 2008;112(7):2703-2708. doi:10.1182/blood-200802-142422

39. Barni S, Labianca R, Agnelli G, et al. Chemotherapy-associated thromboembolic risk in cancer outpatients and effect of nadroparin thromboprophylaxis: results of a retrospective analysis of the PROTECHT study. J Transl Med. 2011;9(1):179. doi:10.1186/14795876-9-179

40. Verso M, Agnelli G, Barni S, Gasparini G, LaBianca R. A modified Khorana risk assessment score for venous thromboembolism in cancer patients receiving chemotherapy: the protecht score. Intern Emerg Med. 2012;7(3):291-292. doi:10.1007/ s11739-012-0784-y

41. Godinho J, Casa-Nova M, Moreira-Pinto J, et al. ONKOTEV score as a predictive tool for thromboembolic events in pancreatic cancer-a retrospective analysis. Oncologist. 2020;25(2):284-290. doi:10.1634/ theoncologist.2019-0510 
42. Salla E, Dimakakos EP, Tsagkouli S, et al. Venous thromboembolism in patients diagnosed with lung cancer. Angiology. 2016;67 (8):709-724. doi:10.1177/0003319715614945

43. Zhang $\mathrm{M}$, Wu S, Hu C. Do lung cancer patients require routine anticoagulation treatment? A meta-analysis. J Int Med Res. 2020;48 (1). doi:10.1177/0300060519896919

44. van Es N, Ventresca M, Di Nisio M, et al. The Khorana score for prediction of venous thromboembolism in cancer patients: an individual patient data meta-analysis. J Thromb Haemost. 2020;18 (8):1940-1951. doi:10.1111/jth.14824

45. Abdel-Razeq H, Tamimi F, Abdel-Razeq R, et al. Predictors of venous thromboembolism in patients with testicular germ cell tumors: a retrospective study. Clin Appl Thromb. 2021;27. doi:10.1177/10760296211024756

46. Bezan A, Posch F, Ploner F, et al. Risk stratification for venous thromboembolism in patients with testicular germ cell tumors. PLoS One. 2017;12(4). doi:10.1371/journal.pone.0176283

47. Kekre N, Connors JM. Venous thromboembolism incidence in hematologic malignancies. Blood Rev. 2019;33:24-32. doi:10.1016/j. blre.2018.06.002

48. Del Principe MI, Del Principe D, Venditti A. Thrombosis in adult patients with acute leukemia. Curr Opin Oncol. 2017;29(6):448-454. doi:10.1097/CCO.0000000000000402

49. Al-Ani F, Wang YP, Lazo-Langner A. Development of a clinical prediction rule for venous thromboembolism in patients with acute leukemia. Thromb Haemost. 2020;120(2):322-328. doi:10.1055/ s-0039-3400303

50. Mitrovic M, Suvajdzic N, Elezovic I, et al. Thrombotic events in acute promyelocytic leukemia. Thromb Res. 2015;135(4):588-593. doi:10.1016/j.thromres.2014.11.026

51. Ku GH, White RH, Chew HK, Harvey DJ, Zhou H, Wun T. Venous thromboembolism in patients with acute leukemia: incidence, risk factors, and effect on survival. Blood. 2009;113(17):3911-3917. doi:10.1182/blood-2008-08-175745

52. Grace RF, DeAngelo DJ, Stevenson KE, et al. The use of prophylactic anticoagulation during induction and consolidation chemotherapy in adults with acute lymphoblastic leukemia. J Thromb Thrombolysis. 2018;45(2):306-314. doi:10.1007/s11239-017-1597-7

53. Rank CU, Lynggaard LS, Als-Nielsen B, et al. Prophylaxis of thromboembolism during therapy with asparaginase in adults with acute lymphoblastic leukaemia. Cochrane Database Syst Rev. 2020; 2020:10. doi:10.1002/14651858.CD013399.pub2

54. Kuderer NM, Poniewierski MS, Culakova E, et al. Predictors of venous thromboembolism and early mortality in lung cancer: results from a Global Prospective Study (CANTARISK). Oncologist. 2018;23(2):247-255. doi:10.1634/theoncologist.2017-0205

55. Mirza AS, Yun S, Al Ali N, et al. Validation of the Khorana score in acute myeloid leukemia patients: a single-institution experience. Thromb J. 2019;17(1):1-6. doi:10.1186/s12959-019-0202-z

56. Antic D, Milic N, Todorovic M, et al. OC-07 - decoding risk for thromboembolic events in lymphoma patients. Thromb Res. 2016;140 (2016):S171. doi:10.1016/s0049-3848(16)30124-4

57. Rupa-Matysek J, Brzeźniakiewicz-Janus K, Gil L, Krasiński Z, Komarnicki M. Evaluation of the ThroLy score for the prediction of venous thromboembolism in newly diagnosed patients treated for lymphoid malignancies in clinical practice. Cancer Med. 2018;7 (7):2868-2875. doi:10.1002/cam4.1540

58. Hohaus S, Tisi MC, Bartolomei F, et al. Risk factors for venous thromboembolism in patients with lymphoma requiring hospitalization. Blood Cancer J. 2018;8(6):1-4. doi:10.1038/ s41408-018-0096-1
59. Bastos-Oreiro M, Ortiz J, Pradillo V, et al. A validation, with new clinical applicability, of a clinical-genetic risk model that predicts thrombosis with high sensitivity in patients with lymphoma. Hematol Oncol. 2019;37:534. doi:10.1002/hon.219_2631

60. Sanfilippo KM, Wang T-F, Luo S, et al. Predictive ability of the khorana score for venous thromboembolism (VTE) in multiple myeloma (MM). J Clin Oncol. 2018;36(15_suppl):e18733-e18733. doi:10.1200/jco.2018.36.15_suppl.e18733

61. Li A, Wu Q, Luo S, et al. Derivation and validation of a risk assessment model for immunomodulatory drug-associated thrombosis among patients with multiple myeloma. J Natl Compr Cancer Netw. 2019;17(7):840-847. doi:10.6004/jnccn.2018.7273

62. Fotiou D, Sergentanis TN, Papageorgiou L, et al. Longer procoagulant phospholipid-dependent clotting time, lower endogenous thrombin potential and higher tissue factor pathway inhibitor concentrations are associated with increased VTE occurrence in patients with newly diagnosed multiple myeloma: results. Blood Cancer J. 2018;8(11). doi:10.1038/s41408-018-0135-y

63. Libourel EJ, Klerk CPW, Van Norden Y, et al. Disseminated intravascular coagulation at diagnosis is a strong predictor for thrombosis in acute myeloid leukemia. Blood. 2016;128(14):1854-1861. doi:10.1182/blood-2016-02-701094

64. Macedo AVS, Ramacciotti E. Is it time for a specific score for venous thromboembolism risk assessment for non-solid tumors? Chinese Clin Oncol. 2019;8(Suppl 1):8-10. doi:10.21037/cco.2019.10.01

65. Hohaus S, Bartolomei F, Cuccaro A, et al. Venous thromboembolism in lymphoma: risk stratification and antithrombotic prophylaxis. Cancers. 2020;12(5):1-17. doi:10.3390/cancers 12051291

66. Kirkizlar O, Alp kirkizlar T, Umit EG, et al. The incidence of venous thromboembolism and impact on survival in Hodgkin lymphoma. Clin Lymphoma Myeloma Leuk. 2020;20(8):542-547. doi:10.1016/j. clml.2020.02.021

67. Rupa-Matysek J, Gil L, Kaźmierczak M, Barańska M, Komarnicki M. Prediction of venous thromboembolism in newly diagnosed patients treated for lymphoid malignancies: validation of the Khorana risk score. Med Oncol. 2018;35(1):1-8. doi:10.1007/ s12032-017-1065-4

68. Borchmann S, Müller H, Hude I, Fuchs M, Borchmann P, Engert A. Thrombosis as a treatment complication in Hodgkin lymphoma patients: a comprehensive analysis of three prospective randomized German Hodgkin Study Group (GHSG) trials. Ann Oncol. 2019;30 (8):1329-1334. doi:10.1093/annonc/mdz168

69. Antic D, Milic N, Nikolovski S, et al. Development and validation of multivariable predictive model for thromboembolic events in lymphoma patients. Am J Hematol. 2016;91(10):1014-1019. doi:10.1002/ajh.24466

70. IMWG Guidelines On VTE in Myeloma Pts. Int myeloma Fn.

71. Streiff MB, Holmstrom B, Ashrani A, et al. Cancer-associated venous thromboembolic disease, version 1.2015: featured updates to the NCCN guidelines. J Natl Compr Cancer Netw. 2015;13(9):10 79-1095. doi:10.6004/jnccn.2015.0133

72. Sanfilippo KM, Luo S, Wang T-F, et al. Predicting venous thromboembolism in multiple myeloma: development and validation of the IMPEDE VTE score. Am J Hematol. 2019;94(11):1176-1184. doi:10. 1002/ajh. 25603 


\section{Publish your work in this journal}

The International Journal of General Medicine is an international, peer-reviewed open-access journal that focuses on general and internal medicine, pathogenesis, epidemiology, diagnosis, monitoring and treatment protocols. The journal is characterized by the rapid reporting of reviews, original research and clinical studies

across all disease areas. The manuscript management system is completely online and includes a very quick and fair peer-review system, which is all easy to use. Visit http://www.dovepress.com/ testimonials.php to read real quotes from published authors. 